

\section{Priestley's England}

\section{MANCHESTER

$$
1824
$$

Manchester University Press 
John Baxendale - 9781847791320 Downloaded from manchesterhive.com at 04/26/2023 01:59:14PM via free access 


\section{Priestley's England}

\section{J. B. Priestley and English culture}

John Baxendale

Manchester University Press

Manchester and New York

distributed exclusively in the USA by Palgrave 
Copyright $\odot$ John Baxendale 2007

The right of John Baxendale to be identified as the author of this work has been asserted by him in accordance with the Copyright, Designs and Patents Act 1988.

Published by Manchester University Press

Oxford Road, Manchester M13 9NR, UK

and Room 400, 175 Fifth Avenue, New York, NY 10010, USA

www.manchesteruniversitypress.co.uk

Distributed exclusively in the USA by

Palgrave, 175 Fifth Avenue, New York,

NY 10010, USA

Distributed exclusively in Canada by

UBC Press, University of British Columbia, 2029 West Mall,

Vancouver, BC, Canada V6T 1Z2

British Library Cataloguing-in-Publication Data

A catalogue record for this book is available from the British Library

Library of Congress Cataloging-in-Publication Data applied for

ISBN 9780719072864 hardback

First published 2007

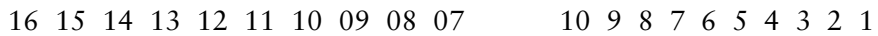

The publisher has no responsibility for the persistence or accuracy of URLs for any external or third-party internet websites referred to in this book, and does not guarantee that any content on such websites is, or will remain, accurate or appropriate.

Typeset in Sabon with Gill Sans display

by Action Publishing Technology Ltd, Gloucester 